\title{
EDITORIAL
}

\section{PARPs and ADP-ribosylation: 60 years on}

\author{
W. Lee Kraus \\ Laboratory of Signaling and Gene Regulation, Cecil H. and Ida Green Center for Reproductive Biology Sciences, University of Texas \\ Southwestern Medical Center, Dallas, Texas 75390, USA
}

Work on PARPs-a family of enzymes that catalyze ADP-ribosylation, a posttranslational modification of proteins-has resulted in major advances and reached important milestones. The past decade has seen new discoveries in areas well beyond the historical focus on DNA repair, which are having impacts on the understanding and treatment of human disease. This special focus section of Genes \& Development includes seven reviews that highlight these discoveries and point the way forward for future advances in the field.

The field of ADP-ribosylation is nearly six decades old, but still faces many unanswered questions. ADP-ribosylation is a posttranslational modification of proteins, in which the ADP-ribose unit of nicotinamide adenine dinucleotide $\left(\mathrm{NAD}^{+}\right)$is covalently linked to specific amino acid acceptor sites in substrate proteins (Gupte et al. 2017). This modification is mediated by a family of enzymes, known as the poly(ADP-ribose) polymerases (PARPs) (Amé et al. 2004). This issue of Genes \& Development contains seven reviews that highlight many of the recent advances on PARPs and ADP-ribosylation. In this Editorial, I provide a brief overview of the field and an introduction to these reviews.

\section{A growing field, coming of age}

Poly(ADP-ribosyl)ation of proteins, in which chains of ADP-ribose units are added onto substrate proteins, was initially discovered by Pierre Chambon and colleagues in 1963 (Chambon et al. 1963). In the ensuing six decades, the field has explored the biochemistry, molecular biology, genetics, and physiology of PARPs and ADP-ribosylation, focusing for many years on the role of PARP-1, the founding member of the family, in DNA repair. More recent studies have led to the identification of a family of PARP enzymes and their involvement in a much broader set of biological processes. This has gone hand in hand with a recognition of the importance of PARPs and ADP-ribosylation in human diseases, as well as the development of PARP inhibitors to treat these diseases. These

[Keywords: ADP-ribosylation; PARPs; posttranslational modification] Corresponding author: lee.kraus@utsouthwestern.edu

Article published online ahead of print. Article and publication date are online at http://www.genesdev.org/cgi/doi/10.1101/gad.336420.120. advances are addressed in detail in the seven reviews included in this issue.

A vibrant and well-established field of biomedical research should reach a number of major milestones, including (1) government-sponsored research programs focused on key topics in the field, (2) an international meeting sponsored by a major conference organization, (3) highimpact publications representing the most forward-looking research in the field, (4) FDA-approved drugs being used in clinics to treat major human diseases, and (5) the attention of the broader scientific community. Although it has taken perhaps longer than one might have expected, the field of PARPs and ADP-ribosylation has reached all of these milestones. This special issue will hopefully contribute to the latter and is being published to coincide with the fourth Cold Spring Harbor Laboratory meeting on "The PARP family and ADP-ribosylation," being held on April 1-4, 2020.

\section{Recent advances in PARPs and ADP-ribosylation}

The reviews presented in this issue cover a range of topics on various aspects of PARPs and ADP-ribosylation that represent some of the major advances in the field made over the past $5-10$ years. These include (1) the study of the enzymology of ADP-ribosylation beyond PARPs, (2) new aspects of the molecular biology and biochemistry of PARPs, (3) new insights into the biology of PARPs and ADP-ribosylation, and (4) the therapeutic potential of inhibiting PARPs and associated enzymes.

One aspect of PARPs and ADP-ribosylation that has advanced quickly is a recognition that the enzymology surrounding ADP-ribosylation is much broader than that contributed solely by the PARP enzymes. This is reflected in new understanding about the role of $\mathrm{NAD}^{+}$biosynthesis in supporting PARP activity, as well as the role of ADPribose removal in determining the biological outcomes of ADP-ribosylation. In this regard, Cohen (2020) discusses how different subcellular pools of $\mathrm{NAD}^{+}$are established, maintained, and regulated to control signaling by PARPs through ADP-ribosylation, while Rack et al. (2020)

(C) 2020 Kraus This article is distributed exclusively by Cold Spring Harbor Laboratory Press for the first six months after the full-issue publication date (see http://genesdev.cshlp.org/site/misc/terms.xhtml). After six months, it is available under a Creative Commons License (AttributionNonCommercial 4.0 International), as described at http://creativecommons.org/licenses/by-nc/4.0/. 
discuss the molecular functions, physiology, and pathology of ADP-ribosyl hydrolases in ADP-ribosyl signaling pathways.

An aspect of PARPs and ADP-ribosylation that has developed considerably over the past decade or so is a greater appreciation of their molecular and biochemical functions in the cell. While the roles of PARPs and ADP-ribosylation in DNA damage detection and repair have long been understood, other aspects of their function (e.g., regulation of RNA, chromatin, and gene expression) have only received attention more recently. Interestingly, if one uses the protein substrates of the nuclear PARPs as an indicator of their biological functions, then RNA biology and gene regulation receive a greater emphasis within the cell than DNA repair (Gibson et al. 2016). Considering a broader view of the diverse molecular and biochemical functions of PARPs and ADP-ribosylation will undoubtedly help the field gain a greater understanding of their biology and therapeutic potential. Two reviews in this issue cover topics in this realm. Azarm and Smith (2020) discuss the role of nuclear PARPs and ADP-ribosylation in genome integrity, including their roles in genome repair, replication, and resolution, while Kim et al. (2020) cover their roles in various aspects of RNA biology, including RNA expression, processing, and splicing; protein translation; and proteostasis.

The past two decades have also witnessed a greater understanding of the vast biology of PARPs and ADP-ribosylation. While the unremarkable phenotypes observed in the first Parp1-null mice reported in 1995 may have cast a pall over the field (Wang et al. 1995), persistence with other genetic models in worms and flies, as well as additional studies in mice, have paid dividends. More specific and focused analyses, especially in response to various stresses, have revealed key roles for PARP-1 in genome surveillance, carcinogenesis, metabolic control, and aging. Moreover, mouse genetic models to study other PARP family members, including PARP-2, PARP-3, PARP-5 (tankyrase), and PARP-7 (TIPARP) have provided a wealth of information about the broader physiology of these enzymes. Two reviews in this issue are devoted to new understanding about the physiology and pathophysiology of PARPs and ADP-ribosylation. Szántó and Bai (2020) discuss the role of PARPs and ADP-ribosylation in metabolic regulation and adipogenesis, while Fehr et al. (2020) highlight the impact of PARPs and ADP-ribosylation on the immune system, inflammation, and host-pathogen interactions.

Finally, a key goal for any field of biomedical science is the translation of its basic science into therapeutics that improve human health. The field has had some major successes in this area, with more sure to come. The discovery that chemical inhibition of PARP-1 results in accumulation of DNA double-strand breaks in BRCA1 and $B R C A 2$ mutant cancer cells and induces cell death via synthetic lethality (Bryant et al. 2005; Farmer et al. $2005)$ led to the approval by the U.S. FDA in 2014 of AstraZeneca's Lynparza (Olaparib) for the treatment of women with advanced ovarian cancer associated with $B R C A 1$ and $B R C A 2$ mutations. This has been followed by the devel- opment and approval of more PARP inhibitor drugs for a broader array of conditions. In her review, Slade (2020) discusses the mechanisms of action and therapeutic potential of inhibitors of PARPs and poly(ADP-ribose) glycohydrolase [PARG, an enzyme that cleaves chains of poly (ADP-ribose)] in cancer treatment.

Collectively, these reviews highlight some of the major recent advances in the field made over the past 5-10 years.

\section{W. Lee Kraus, Ph.D. Guest Editor}

\section{Competing interest statement}

W.L.K. is a founder and consultant for Ribon Therapeutics, Inc. He is also coholder of U.S. patent 9,599,606 covering a set of ADP-ribose detection reagents, which has been licensed to and is sold by EMD Millipore.

\section{Acknowledgments}

I thank the members of my laboratory for their continuing discoveries that have helped to increase our understanding of PARPs and ADP-ribosylation. The PARP-related research in W.L.K.'s laboratory is supported by a grant from the National Institutes of Health/National Institute of Diabetes and Digestive and Kidney Diseases (R01 DK069710), grants from Cancer Prevention and Research Institute of Texas (RP160319 and RP190236), and funds from the Cecil H. and Ida Green Center for Reproductive Biology Sciences Endowment to W.L.K.

\section{References}

Amé JC, Spenlehauer C, de Murcia G. 2004. The PARP superfamily. Bioessays 26: 882-893. doi:10.1002/bies.20085

Azarm K, Smith S. 2020. Nuclear PARPs and genome integrity. Genes Dev (this issue). doi:10.1101/gad.334730.119

Bryant HE, Schultz N, Thomas HD, Parker KM, Flower D, Lopez E, Kyle S, Meuth M, Curtin NJ, Helleday T. 2005. Specific killing of BRCA2-deficient tumours with inhibitors of poly/ADPribose) polymerase. Nature 434: 913-917. doi:10.1038/ nature 03443

Chambon P, Weill JD, Mandel P. 1963. Nicotinamide mononucleotide activation of a new DNA-dependent polyadenylic acid synthesizing nuclear enzyme. Biochem Biophys Res Commun 11: 39-43. doi:10.1016/0006-291X|63|90024-X

Cohen MS. 2020. Interplay between compartmentalized NAD ${ }^{+}$ synthesis and consumption: a focus on the PARP family. Genes Dev (this issue). doi:10.1101/gad.335109.119

Farmer H, McCabe N, Lord CJ, Tutt AN, Johnson DA, Richardson TB, Santarosa M, Dillon KJ, Hickson I, Knights C, et al. 2005. Targeting the DNA repair defect in BRCA mutant cells as a therapeutic strategy. Nature 434: 917-921. doi:10.1038/ nature 03445

Fehr A, Singh SA, Kerr CM, Mukai S, Higashi H, Aikawa M. 2020. The impact of PARPs and ADP-ribosylation on inflammation and host-pathogen interactions. Genes Dev (this issue). doi:10 $.1101 /$ gad.334425.119

Gibson BA, Zhang Y, Jiang H, Hussey KM, Shrimp JH, Lin H, Schwede F, Yu Y, Kraus WL. 2016. Chemical genetic discovery of PARP targets reveals a role for PARP-1 in transcription elongation. Science 353: 45-50. doi:10.1126/science.aaf7865 
Gupte R, Liu Z, Kraus WL. 2017. PARPs and ADP-ribosylation: Recent advances linking molecular functions to biological outcomes. Genes Dev 31: 101-126. doi:10.1101/gad.291518 .116

Kim D-S, Challa S, Jones A, Kraus WL. 2020. PARPs and ADPribosylation in RNA biology: from RNA expression and processing to protein translation and proteostasis. Genes Dev (this issue). doi:10.1101/gad.334433.119

Rack JGM, Palazzo L, Ahel I. 2020. (ADP-ribosyl)hydrolases: structure, function, and biology. Genes Dev (this issue). doi:10.1101/gad.334631.119
Slade D. 2020. PARP and PARG inhibitors in cancer treatment. Genes Dev (this issue). doi:10.1101/gad.334516.119

Szántó M, Bai P. 2020. The role of ADP-ribose metabolism in metabolic regulation, adipose tissue differentiation, and metabolism. Genes Dev (this issue). doi:10.1101/gad.334284 .119

Wang ZQ, Auer B, Stingl L, Berghammer H, Haidacher D, Schweiger M, Wagner EF. 1995. Mice lacking ADPRT and poly(ADP-ribosyl)ation develop normally but are susceptible to skin disease. Genes Dev 9: 509-520. doi:10.1101/gad.9.5 .509 


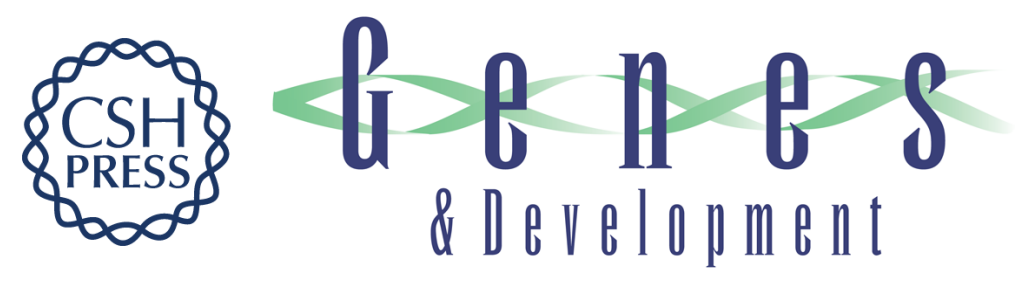

\title{
PARPs and ADP-ribosylation: 60 years on
}

\author{
W. Lee Kraus
}

Genes Dev. 2020, 34: originally published online February 6, 2020

Access the most recent version at doi:10.1101/gad.336420.120

\section{Related Content}

References

Creative Commons License

Email Alerting Service
Interplay between compartmentalized NAD+ synthesis and consumption: a focus on the PARP family

Michael S. Cohen

Genes Dev. March , 2020 34: 254-262 Nuclear PARPs and genome integrity

Kameron Azarm and Susan Smith

Genes Dev. March , 2020 34: 285-301 The role of ADP-ribose metabolism in metabolic regulation, adipose tissue differentiation, and metabolism Magdolna Szántó and Peter Bai

Genes Dev. March , 2020 34: 321-340 PARP and PARG inhibitors in cancer treatment Dea Slade

Genes Dev. March , 2020 34: 360-394 PARPs and ADP-ribosylation in RNA biology: from RNA expression and processing to protein translation and proteostasis Dae-Seok Kim, Sridevi Challa, Aarin Jones, et al.

Genes Dev. March , 2020 34: 302-320 (ADP-ribosyl)hydrolases: structure, function, and biology

Johannes Gregor Matthias Rack, Luca Palazzo and Ivan Ahel

Genes Dev. March , 2020 34: 263-284 The impact of PARPs and ADP-ribosylation on inflammation and hostpathogen interactions

Anthony R. Fehr, Sasha A. Singh, Catherine M. Kerr, et al.

Genes Dev. March , 2020 34: 341-359

This article cites 14 articles, 10 of which can be accessed free at: http://genesdev.cshlp.org/content/34/5-6/251.full.html\#ref-list-1

Articles cited in: http://genesdev.cshlp.org/content/34/5-6/251.full.html\#related-urls

This article is distributed exclusively by Cold Spring Harbor Laboratory Press for the first six months after the full-issue publication date (see

http://genesdev.cshlp.org/site/misc/terms.xhtml). After six months, it is available under a Creative Commons License (Attribution-NonCommercial 4.0 International), as described at http://creativecommons.org/licenses/by-nc/4.0/.

Receive free email alerts when new articles cite this article - sign up in the box at the top right corner of the article or click here.

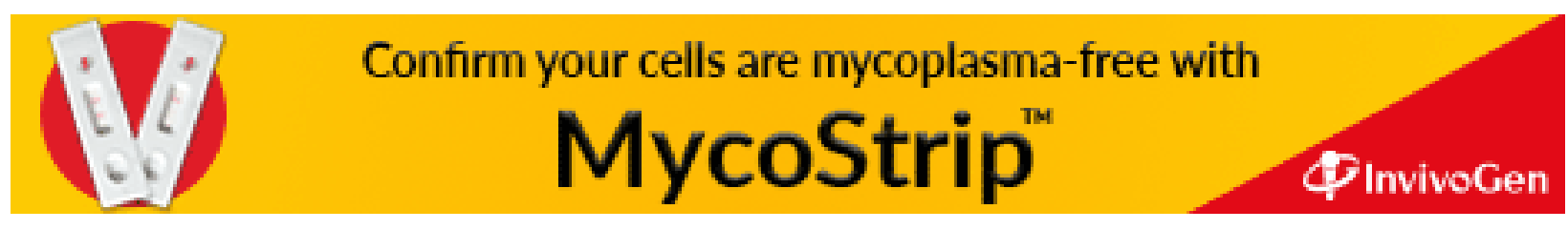

